Journal of Southeast Asian

\title{
The Feast of First Mourning
}

Sumeia Williams

sume9000@yahoo.com

Follow this and additional works at: https://docs.lib.purdue.edu/jsaaea

Part of the Asian American Studies Commons, Poetry Commons, and the Social Work Commons

\section{Recommended Citation}

Williams, Sumeia (2007) "The Feast of First Mourning," Journal of Southeast Asian American Education and Advancement. Vol. 2 : Iss. 1, Article 7.

DOI: $10.7771 / 2153-8999.1089$

Available at: https://docs.lib.purdue.edu/jsaaea/vol2/iss1/7

This document has been made available through Purdue e-Pubs, a service of the Purdue University Libraries. Please contact epubs@purdue.edu for additional information.

This is an Open Access journal. This means that it uses a funding model that does not charge readers or their institutions for access. Readers may freely read, download, copy, distribute, print, search, or link to the full texts of articles. This journal is covered under the CC BY-NC-ND license. 


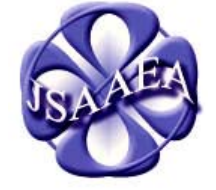

Volume 2

\section{Journal of Southeast Asian American \\ Education \& Advancement \\ WWw.JSAAEA.org}

A peer-reviewed

scholarly journal

published by the

National Association

for the Education \&

Advancement of

Cambodian, Laotian,

and Vietnamese

Americans (NAFEA)

\section{The Feast of First Mourning \\ by \\ Sumeia Williams}

Má, how is it that you flow through my veins

yet I possess the least of you?

I was born twice before my thôi nôi, a daughter born of flesh

before being rewritten on paper.

My soldier father left Việt Nam in 1970

but before he boarded the plane, he buried his memory of Má

beside the runway.

With a duffel bag of souvenirs under one arm and I, in the crook of another, he left without ever asking her name.

Years later he would recall how I'd howled and kicked from Sài Gòn to Honolulu.

"It was war," I'm told, as if that should explain why

Má didn't exist

before my fourteenth birthday.

Unable to accept that my blood

flowed in another direction,

my American mother never spoke of Việt Nam,

COMARERIGHISRESEREDDReaders are free to copy, display, and distribute this article, as long as the work is attributed to the author(s) and the Journal of Southeast Asian American Education \& Advancement, it is distributed for non-commercial purposes only, and no alteration or transformation is made in the work. More details of this Creative Commons license are available at http://creativecommons.org/licenses/by-ncnd/2.5/. All other uses must be approved by the author(s) or JSAAEA. 
but the maternal compass

that had first mapped my veins

left markers that kept Sài Gòn

firmly imprinted in the corner of my eye.

Cung chúc tân xuân, Má. Happy New Year.

A mother in neither name nor memory, it pains me to think that until now she has eaten alone or not at all on the Feast of the First Morning.

Forgive me, Má, for letting over thirty years pass

before I lit incense for your ngày gió.

The wisps of smoke hang suspended before an alter still craving a face.

The empty picture frame holds nothing but questions and laminated adoption documents

that offer no resolution for a severed bloodline that's been cauterized with the words

"born of unknown parents."

Má, come feast with your American daughter

on what has become your death anniversary.

I have nothing of substance

to entice her back among the living, only my words as I rewrite her

into existence

knowing she was

and can be again

because I am here. 


\section{About the Author}

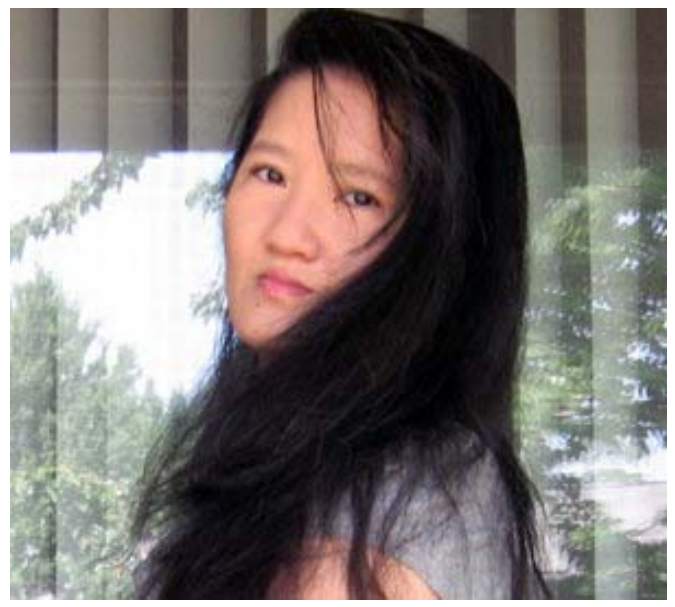

Sumeia Williams was born in Saigon, Vietnam in 1970. Formerly, Le Thi Buu Tran, she was renamed after her adoption. She is currently living North Carolina as a mom to four kids and a part-time writer. Her poems and essays have appeared in places like Azizah Magazine, Nha Magazine, The Iodine Poetry Journal and will appear in an upcoming anthology, Not Forgotten: Asian Americans Remember US Wars in Asia. 


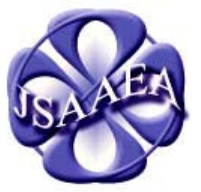

Volume 2

\section{Journal of Southeast Asian American Education \& Advancement WWW.JSAAEA.org}

\section{Editor}

Dr. Wayne E. Wright

University of Texas, San Antonio

Associate Editors

Dr. Chhany Sak-Humphry

University of Hawaii

Dr. KimOanh Nguyen-Lam

California State University, Long Beach

Book Review Editor

Dr. Leslie Turpin

School for International Training

\section{Creative Works Editor}

Phouang Hamilton

Washington Office of Superintendent of Public Instruction

\section{Special Advisor}

Anne Frank

University of California, Irvine, Southeast Asian Archives

\section{Editorial Assistant}

Shereen Bhalla

University of Texas, San Antonio
A peer-reviewed scholarly journal published by the National Association for the Education \& Advancement of Cambodian, Laotian, and Vietnamese Americans (NAFEA)

Comments and questions for the editorial staff may be directed to jisaaea@lists.sis.utsa.edu

\section{Editorial Review Board}

Dr. Carl L. Bankston III

Tulane University

Dr. Pollie Bith-Melander

San Jose State University

Dr. Phala Chea

Lowell Public Schools

Dr. George Chigas

University of Massachusetts, Lowell

Dr. Changming Duan

University of Missouri, Kansas City
Dr. Sophal Ear

Syracuse University

Dr. Nancy H. Hornberger

University of Pennsylvania

Dr. Samlong Inthaly

Minneapolis Public Schools

Dr. Peter Nien-Chu Kiang

University of Massachusetts, Boston 


\author{
Dr. Kevin K. Kumashiro \\ University of Illinois, Chicago \\ Dr. Stacey Lee \\ University of Wisconsin, Madison \\ Dr. David Chanpannha Ley \\ Montgomery County Public Schools \\ Dr. Sue Needham \\ California State University, Dominguez Hills \\ Dr. Bic Ngo \\ University of Wisconsin-Madison \\ Dr. Max Niedzwiecki \\ Rights Working Group \\ Dr. Leakhena Nou \\ California State University, Long Beach \\ Dr. Clara Park \\ California State University, Northridge \\ Dr. Mark Pfeifer \\ Texas A\&M University, Corpus Christi \\ Dr. Loan T. Phan \\ University of New Hampshire \\ Dr. Bounlieng Phommasouvanh \\ Minnesota Department of Education
}

\author{
Dr. Karen Quintiliani \\ California State University, Long Beach \\ Dr. Kalyani Rai \\ University of Wisconsin, Milwaukee \\ Dr. Fay Shin \\ California State University, Long Beach \\ Dr. Nancy J. Smith-Hefner \\ Boston University \\ Dr. Yer J. Thao \\ Portland State University \\ Dr. Myluong Tran \\ San Diego State University \\ Dr. Khatharya Um \\ University of California, Berkeley \\ Dr. Linda Trinh Vo \\ University of California, Irvine \\ Dr. Terrence G. Wiley \\ Arizona State University \\ Dr. Zha Blong Xiong \\ University of Minnesota \\ Dr. Kou Yang \\ California State University, Stanislaus
}

\section{Doctoral Student \\ Editorial Review Board}

\author{
Keo Chea \\ University of Pennsylvania \\ Vichet Chhuon \\ University of California, Santa Barbara \\ Loan Dao \\ University of California, Berkeley \\ Annie BichLoan Duong \\ San Joaquin County Office of Education \\ Ha Lam \\ Arizona State University \\ Ravy Lao \\ University of California, Santa Barbara \\ Vanna Som \\ Harvard University
}

Rassamichanh Souryasack

University of California, Santa Barbara

$$
\begin{gathered}
\text { Giang Tang } \\
\text { University of Minnesota }
\end{gathered}
$$

Layheng Ting

State University of New York, Albany

Loan Tran

University of California, Santa Barbara

Phitsamay Sychitkokhong Uy

Harvard University

Yang Sao Xiong

University of California, Los Angeles 